Article

\title{
Preparation of a Water-Based Photoreactive Azosulphonate-Doped Poly(Vinyl Alcohol) and the Investigation of Its UV Response
}

\author{
Philipp Nothdurft, Jörg Guido Schauberger®, Gisbert Riess * and Wolfgang Kern
}

Chair in Chemistry of Polymeric Materials, Montanuniversitaet Leoben, Otto-Glöckel-Straße 2, A-8700 Leoben, Austria; phino@gmx.net (P.N.); jgschauberger@gmail.com (J.G.S.); wolfgang.kern@unileoben.ac.at (W.K.)

* Correspondence: gisbert.riess@unileoben.ac.at

Received: 14 December 2018; Accepted: 11 January 2019; Published: 18 January 2019

\begin{abstract}
Two different azosulphonate dyes were synthesised and purified for the preparation of a water-based photoreactive azosulphonate-doped poly(vinyl alcohol). The aim was the investigation of a novel azosulphonate-poly(vinyl alcohol) photoresist with decreased water solubility after illumination, setting a focus on environmentally benign substances. The electron distribution of the aromatic rings of the two different azosulphonate molecules were changed by the UV-induced cleavage of the $-\mathrm{N}=\mathrm{N}-\mathrm{SO}_{3}{ }^{-}$groups, which was evidenced by UV spectroscopy. The formation of ester groups was detected by Fourier-transform infrared and ${ }^{13} \mathrm{C}$ nuclear magnetic resonance spectroscopy. UV-Vis spectroscopy was used to investigate the photoreactivity of the prepared films. Photolithographic experiments demonstrated the applicability of these newly produced materials as photoresist materials. In addition, these materials provide high thermal stability.
\end{abstract}

Keywords: coatings; crosslinking; photochemistry; poly(vinylalcohol); azosulphonate; photoresist

\section{Introduction}

In recent decades, environmental compliance has come to be of growing importance in industry and for the application of chemical technologies and materials. Hence, production processes have to be adapted, solvents and process chemicals have to be recirculated, and the overall ecological footprint should be reduced. The substitution of established processes, chemicals and materials by water-based systems would pose alternatives that are environmentally benign, as well as leading to cost reductions after implementation.

For example, modern photoresist materials are, in general, formulated in organic solvents, developed in strong alkaline aqueous solutions, and used for the production of circuit boards, flat panel displays, television screens and semiconductor devices [1,2]. In recent years, the development of water-based photoresist has gained more and more attention [3-6]. The advantage of this system is that it can simplify the imaging process while being more environmentally desirable.

One potential candidate for a water-based photoresist material is poly(vinyl alcohol) (PVA). PVA is usually prepared by polymer-analogous saponification of poly(vinyl acetate) which has been polymerised by free radical polymerisation [7]. Nowadays, PVA is employed as an adhesive for packaging applications [8], a sizing agent for paper processing [9,10], a water-soluble glue and modelling material [8], an encapsulation agent, and a dispersing aid [11]. Due to its biocompatibility, this polymer is regarded as safe for coatings in contact with foodstuff and suitable for the preparation of hydrogels for biomedical applications [12,13]. 
PVA is highly polar and exhibits strong hygroscopy. Thus, the formation of crosslinks between the polymer chains would lead to a reduction of the water solubility. Poly(vinyl alcohol) can be crosslinked by acid-catalysation methods or by radiation [14-17]. Exposure to ionising radiation such as $\beta / \gamma$-rays or X-rays results in a statistic formation of free radicals and their subsequent recombination [18]. A more convenient method to crosslink PVA is doping with transition metal chlorides such as iron chloride, or chromates such as potassium dichromate, which leads to photosensitising of the polymer. The mechanism of crosslinking can be compared to the well-known gelatine/dichromate systems in the field of photographic and holographic recording materials. It has to be stated that chromates are highly toxic compounds, which are hazardous to the environment and are carcinogenic as well [19].

Manivannan, Kuncser and Filoti investigated the mechanism of crosslinking for $\mathrm{Fe}^{3+}$-doped PVA and found that photoreduction of the $\mathrm{Fe}^{3+}$ ions to $\mathrm{Fe}^{2+}$ takes place, which leads to radical formation and recombination, thus leading to crosslink formation $[17,20]$. $\mathrm{As} \mathrm{FeCl}_{3}$ is employed as flocculation agent for waste water treatment, it is considered environmentally benign and poses an alternative to chromate doping of PVA $[17,20]$. Schauberger took up and continued the idea of iron doping of PVA $[16,21]$. Here, $\mathrm{Fe}^{2+}$ was intercalated in montmorillonite and PVA/montmorillonite composites were UV-irradiated. Crosslinking was evidenced, and as a result, the gel content increased to $90 \%$.

Another approach to obtain UV-curable PVA is the grafting of copolymers with acrylic moieties attached to the polymer backbone. By the addition of a radical photoinitiator such as 2-hydroxy-2-methylpropiophenone (Irgacure ${ }^{\circledR} 1173 ;$ BASF GmbH; Ludwigshafen; Germany), UV-induced crosslinking via free radical reaction can be performed, which leads to a material that is insoluble in deionised water [22].

In this paper, the focus was set on covalently bound azosulphonates as potential crosslinking agents. It was shown by Overberger and Nuyken that thermally cleavable azo compounds can be used as initiators for free radical polymerisation [23,24]. In the early 1990s, Riess, Nuyken and Voit [23,25-27] investigated photoactive aryl azosulphonate dyes for the preparation of UV-active resins and polymers and studied their decomposition behaviour. It was found that the chemical environment is responsible for the decomposition mechanism (Figure 1).

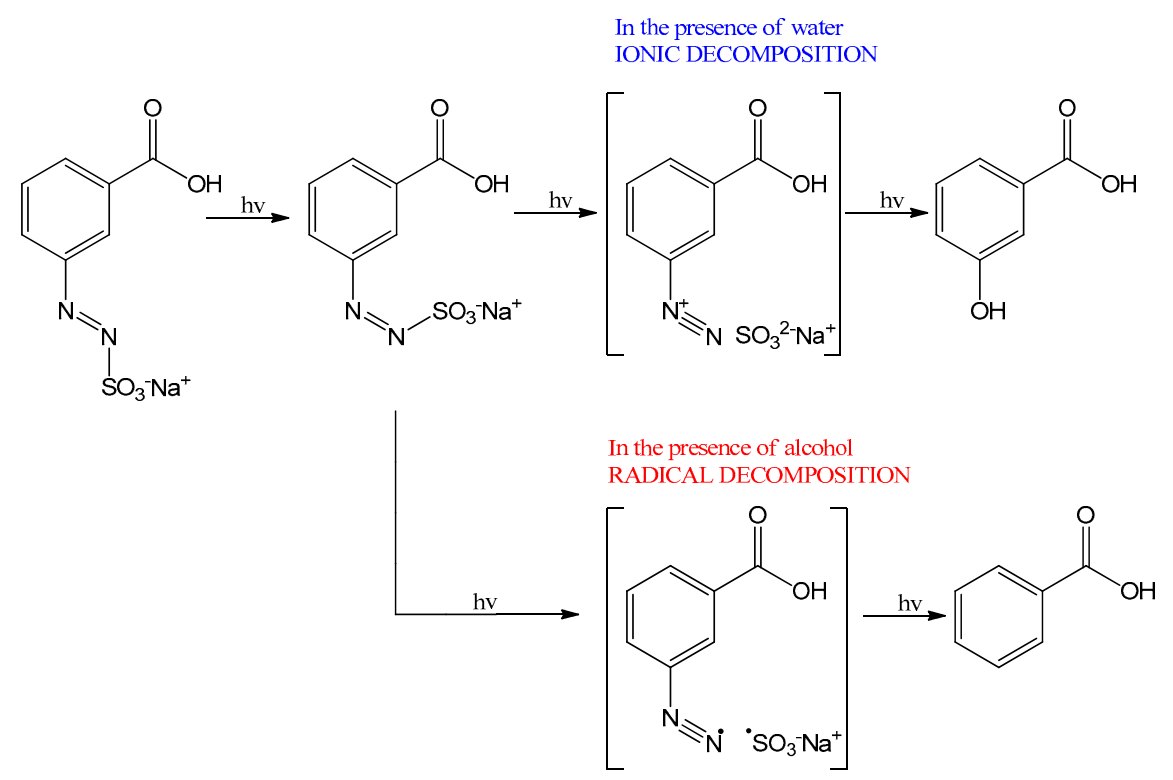

Figure 1. Decomposition mechanism of aryl azosulphonate compounds dependent on the chemical environment, as published by Nuyken, Voit and Riess (copyright permission by Riess) [23,26].

Generally, the presence of water causes an ionic scission mechanism, which leads to the formation of hydroxyphenyl groups. In contrast to this, phenyl groups are formed due to the radical cleavage mechanism, caused by the presence of alcohols. The UV-induced decomposition leads to the formation 
of nitrogen gas, showing no dependence on the chemical environment $[23,26,28]$. Today, photolabile and thermally low molecular aromatic azo compounds are employed in the field of photoresist materials, laser ablation and recording materials $[26,29,30]$.

The aim of this work is to provide a novel PVA photoresist material with decreased water solubility after illumination, based on environmentally benign materials and reaction conditions.

\section{Materials and Methods}

\subsection{Materials}

3-amino isophthalic acid, 3-amino benzoic acid, sodium sulphite, sodium carbonate and sodium nitrite were obtained from Sigma-Aldrich Co. (Vienna, Austria), Hydrochlorid acid was obtained from Carl Roth GmbH Co. KG (Karlsruhe, Germany). These chemicals were used without any further purification or particular treatment. PVA was provided by DuPont Chemical Company (Lenzing, Austria) and characterised prior to use.

\subsection{Methods}

\subsubsection{Synthesis of the Azosulphonate Sodium Salts}

For the synthesis of 3,5-dicarboxylphenyl azosulphonate sodium salt (AZOII), $200 \mathrm{mmol}$ of 3 -amino isophthalic acid was dissolved in $100 \mathrm{~mL}$ of hydrochloric acid solution $(10 \mathrm{wt} \%$ in deionised water) and cooled to $0{ }^{\circ} \mathrm{C}$ in an ice bath. Diazotation took place by reaction of the amino groups with $100 \mathrm{~mL}$ of a sodium nitrite solution (2 M). Furthermore, the suspension was slowly added into a solution of sodium sulphite $(240 \mathrm{mmol})$ and sodium carbonate $(300 \mathrm{mmol})$ at $0{ }^{\circ} \mathrm{C}$ while stirring continuously.

The resultant orange mixture reaction was stored in a refrigerator at $0-5^{\circ} \mathrm{C}$ for $18 \mathrm{~h}$. Afterwards, the $\mathrm{pH}$ was adjusted by adding concentrated hydrochloric acid until a value of $\mathrm{pH} 2$ was reached. The resulting precipitate was filtered, dried at $50{ }^{\circ} \mathrm{C}$ and ground in an agate mortar to achieve a fine powder. The product was purified by recrystallisation from warm water.

The synthesis of 3-carboxyphenyl azosulphonate sodium salt (AZOIII) was performed in a similar way. As precursor material, 3-amino benzoic acid was used, and the amount of the solution comprising sodium sulphite and sodium carbonate was reduced to 200 and $150 \mathrm{mmol}$, respectively. All other reaction steps were kept the same.

\subsubsection{Photolysis}

The light-induced decomposition reactions of the azosulphonate sodium salts (Figure 1) were investigated via FTIR and UV-Vis spectroscopy. Therefore, aqueous solutions of AZOII and AZOIII compounds were prepared.

For FTIR spectroscopy, $\mathrm{CaF}_{2}$ platelets were coated with a thin layer of the respective azosulphonate salt, irradiated for a period of time (0-900 s), and transmission spectra in the range of $1800-850 \mathrm{~cm}^{-1}$ were recorded. The main focus was on Ar-N $\left(1300-1250 \mathrm{~cm}^{-1}\right),-\mathrm{N}=\mathrm{N}-\left(1260-1235 \mathrm{~cm}^{-1}\right)$ and $-\mathrm{N}-\mathrm{S}-$ $\left(1055 \mathrm{~cm}^{-1}\right)$ absorption bands due to decomposition during illumination. In addition, the possible formation of hydroxyphenyl groups due to the presence of aerial humidity was investigated. FTIR spectra were recorded with a PerkinElmer Spectrum One instrument (PerkinElmer Inc., Waltham, MA, USA).

Changes in the electron density of the aromatic ring at different irradiation times (0-210 s) were monitored by UV-Vis spectroscopy. The absorption spectra were recorded in the spectral range from 200 to $800 \mathrm{~nm}$ in a quartz cuvette. UV-Vis spectra were taken with an Agilent Cary 50 instrument (Agilent Technologies, Santa Clara, CA, USA).

The irradiation was conducted by using a spot curing device (high pressure mercury vapour UV light source) with a power output of $9.25 \mathrm{~mW} \cdot \mathrm{cm}^{-2}$. 


\subsubsection{Thermolysis}

The thermal stability and the decomposition temperature of the azosulphonate salts were investigated via thermogravimetric measurements (TGA). Samples were placed in aluminium oxide crucibles and analysed. Nitrogen was used as purge gas with a flow rate of $30 \mathrm{~mL} \cdot \mathrm{min}^{-1}$ and the measurement was performed at a heating rate of $20 \mathrm{~K} \cdot \mathrm{min}^{-1}$. A PerkinElmer Pyris 7 (PerkinElmer Inc., Waltham, MA, USA) was used for these measurements.

\subsubsection{Preparation of Azosulphonate-Doped PVA}

PVA was characterised prior to use by means of gel-permeation chromatography (GPC) and ${ }^{1}$ H-NMR spectroscopy. GPC was performed at the Department of Physical and Theoretical Chemistry at the University of Graz; NMR spectra were recorded with a $400 \mathrm{MHz}$ Agilent NMR spectrometer (Santa Clara, United States). A polydispersity index of 1.32 and a Mw of 130,000 g/mol were determined, and the specified degree of saponification (>99 mol \%) was confirmed.

The aqueous PVA solution with a solid content of $5 \mathrm{wt} \%$ was obtained by addition of PVA to deionised water under stirring. After $10 \mathrm{~min}$, the slurry was heated to a temperature of $85^{\circ} \mathrm{C}$ for at least $60 \mathrm{~min}$ to obtain a homogeneous solution.

The respective azosulphonate-doped PVAs (PAII and PAIII) were prepared as follow: The appropriate amount of the azosulphonate salt (Table 1) was dissolved in the $5 \mathrm{wt} \%$ aqueous PVA solution at a $\mathrm{pH}$ value of 3 adjusted with hydrochloric acid. For a better distribution of the azosulphonates, the samples were treated by sonication and stirred at $60{ }^{\circ} \mathrm{C}$. The solutions were stored at room temperature in brown glass vials to prevent light-induced decomposition of the PVA-AZO compounds.

Table 1. Composition of PVA-AZO formulations (with regard to the dry content).

\begin{tabular}{cccc}
\hline Notation & PVA (wt \%) & AZOII (wt \%) & AZOIII (wt \%) \\
\hline PAII.1 & 97.5 & 2.5 & \\
PAII.2 & 95 & 5 & \\
PAII.3 & 92.5 & 7.5 & \\
PAII.4 & 90 & 10 & \\
PAII.5 & 80 & 20 & \\
PAIII.1 & 97.5 & & 5.5 \\
PAIII.2 & 95 & & 7.5 \\
PAIII.3 & 92.5 & & 10 \\
PAIII.4 & 90 & & 5 \\
\hline
\end{tabular}

\subsubsection{PVA-AZO Thin Film Preparation}

The gravity settling method was used for preparing thin films (GS films). Therefore, $10 \mathrm{~g}$ of the solution was poured into polystyrene petri dishes with a diameter of $85 \mathrm{~mm}$, and dried under constant air flow at room temperature. Thin films were also produced by drop casting on $\mathrm{CaF}_{2}$ disks (DC films). A drop of the respective PVA-AZO solution was placed on the $\mathrm{CaF}_{2}$ crystal, and the solvent was evaporated.

\subsubsection{Annealing}

The prepared GS films, as well as the coated $\mathrm{CaF}_{2}$ platelets, were heat-treated at $100{ }^{\circ} \mathrm{C}$ using a circulating air oven for 5 to $60 \mathrm{~min}$. FTIR spectra were recorded of the thin DC films prior and after annealing to determine the anticipated formation of ester bonds. In addition, the films were irradiated with a high-pressure mercury vapour UV light $0-300 \mathrm{~s}$. and the reaction kinetics were monitored by UV-Vis spectroscopy. 
Additionally, sample PAII.5 and sample PAIII.5 (see Table 1) were analysed by ${ }^{13} \mathrm{C}$ NMR measurements. Non-heat-treated and heat-treated thin films (annealed at $100{ }^{\circ} \mathrm{C}$ for $60 \mathrm{~min}$ ) were dissolved in deuterated water $\left(\mathrm{D}_{2} \mathrm{O}\right)$ at $85^{\circ} \mathrm{C}$. The changes in the NMR spectra were monitored.

\subsubsection{Photolithographic Patterning}

Photolithographic patterning was performed by placing a quartz/chromium mask with 100-micron features onto thin PVA-AZO films, followed by illumination with a medium-pressure mercury vapour emitter with an intensity of $740 \mathrm{~mW} \cdot \mathrm{cm}^{-2}$ for $60 \mathrm{~s}$. To enhance the visualisation of the pattern caused by decomposition of the azo dyes, a combination of phase contrast imaging and polarised light imaging was employed. Optical micrographs were recorded after patterning and after development in deionised water.

\section{Results and Discussion}

\subsection{Characterisation of the Azosulphonate Sodium Salts}

The two-step synthesis of water-soluble aryl azosulphonates bearing carboxylic moieties on the aromatic ring is shown in Figure 2.<smiles>Nc1cc(C(=O)O)cc(C(=O)O)c1</smiles>

3-amino isophthalic acid<smiles>N#[N+][O-]</smiles>

3,5-dicarboxylphenyl azosulphonate sodium salt (AZOII)<smiles>Nc1cccc(C(=O)O)c1</smiles>

3-amino benzoic acid

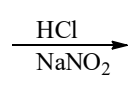

(1)<smiles>N#[N+]c1cccc(C(=O)O)c1</smiles>

3-carboxylphenyl azosulphonate sodium salt (AZOIII)

Figure 2. Two-step synthesis of water-soluble aryl azosulphonates.

A reaction yield of $30 \%(60 \mathrm{mmol})$ for AZOII and $38 \%(76 \mathrm{mmol})$ for AZOIII was calculated. The obtained azosulphonate dyes were dissolved in deuterated water (D2O) followed by ${ }^{1} \mathrm{H}$ and ${ }^{13} \mathrm{C}$ NMR measurements to evaluate the products, as well as their purity. The spectra for AZOII and AZOIII are depicted in Figures 3 and 4, respectively.

The protons of the aromatic ring of AZOII can be assigned to the peaks at 8.6 and $8.5 \mathrm{ppm}$ (meta position, Figure 3a). The remaining hydrogen atom is therefore related to the peak at $7.6 \mathrm{ppm}$. As additional chemical shifts between 7.6 and $8.5 \mathrm{ppm}$ are detected, it is assumed that these additional peaks are a result of partial deprotonation of the carboxylic moieties, by changing the dipole moment of the molecules [26,31]. 

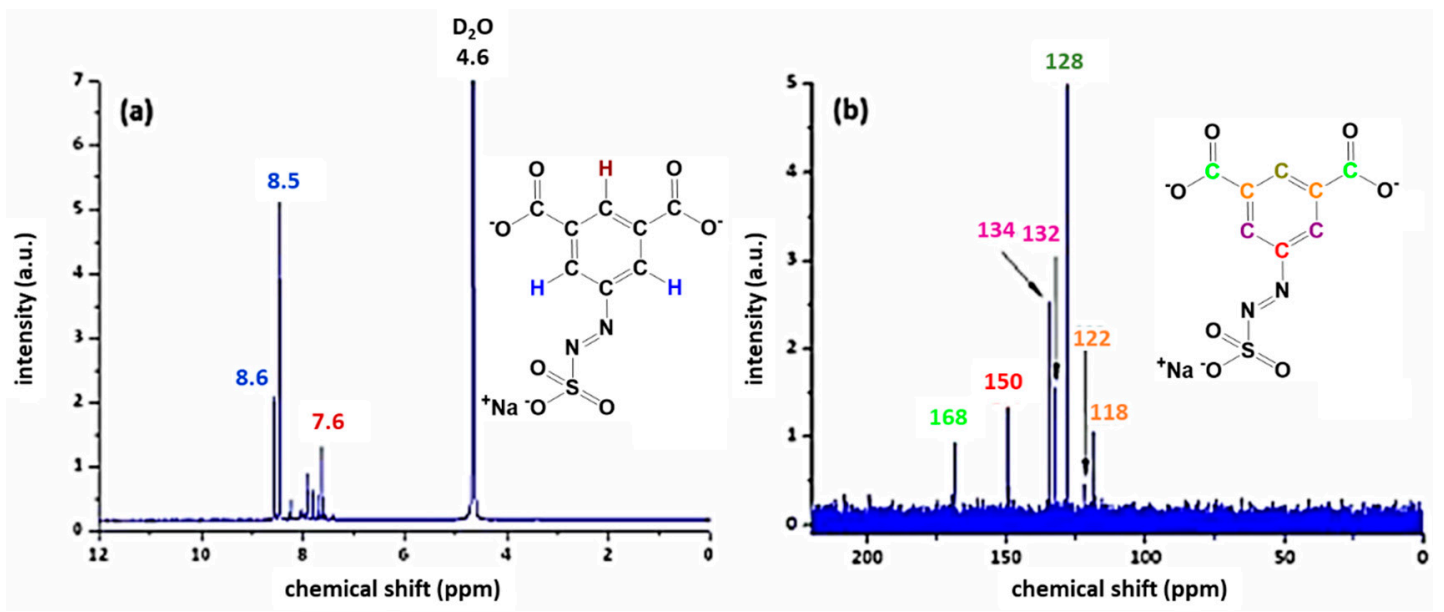

Figure 3. ${ }^{1} \mathrm{H}$ (a) and ${ }^{13} \mathrm{C}$ (b) NMR spectra of AZOII dissolved in deuterated water.

The ${ }^{13} \mathrm{C}$ NMR spectrum of AZOII is not affected by the deprotonation, each of the carbon atoms can be assigned to a specific peak. The carboxylic acid groups can be attributed to the peak at $169 \mathrm{ppm}$, while the $-\mathrm{C}-\mathrm{N}=\mathrm{N}-\mathrm{SO}_{3}{ }^{-}$shift is detected at $150 \mathrm{ppm}$. The remaining five carbon atoms of the aromatic ring can be assigned to the chemical shifts between 134 and 118 ppm and are colour coded in Figure 3b.

In accordance with the results for AZOII, the ${ }^{1} \mathrm{H}$ NMR spectrum of AZOIII (Figure 4a) reveals the deprotonation of the carboxylic moiety of the azo dye; otherwise, a signal at a chemical shift of $11 \mathrm{ppm}$ would be detectable (signal of the $\mathrm{COOH}$ proton). The other hydrogen atoms of the aromatic system are unambiguously assigned to a specific chemical shift whereby the change of the dipole moment by only one carboxylic moiety is not as strong as for the AZOII dye.
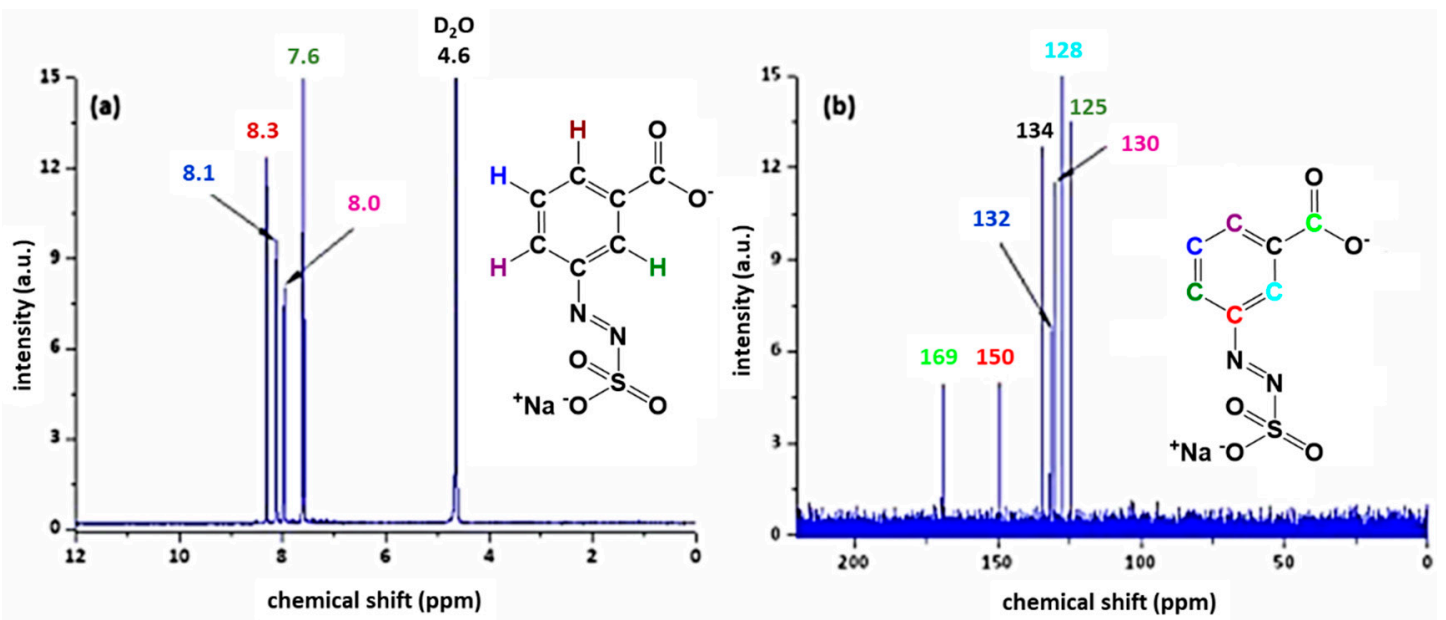

Figure 4. ${ }^{1} \mathrm{H}$ (a) and ${ }^{13} \mathrm{C}(\mathbf{b})$ NMR spectra of AZOIII dissolved in deuterated water.

The ${ }^{13} \mathrm{C}$ NMR spectrum of AZOIII exhibits a strong signal of the carboxylic moiety at $169 \mathrm{ppm}$, as well as the $\mathrm{Ar}-\mathrm{N}=\mathrm{N}-\mathrm{SO}_{3}{ }^{-}$shift at $150 \mathrm{ppm}$. The position of the carbon atoms of the aromatic ring is colour coded in the range of 134 to $125 \mathrm{ppm}$ (see Figure $4 \mathrm{~b}$ ).

From these results, the high purity of the synthesised azosulphonate dyes was evaluated. The dyes were used for the subsequent experiments.

\subsection{Behaviour of the Synthesised Azosulphonate Dyes under Thermal Load and UV Light}

Photolysis and thermolysis experiments were performed to investigate the thermal stability and the UV sensitivity of both newly synthesised molecules. 
The carboxylic moieties of the AZOII and AZOIII dyes are partly deprotonated, which is observable by the formation of absorption bands at 1610-1550 and 1420-1300 $\mathrm{cm}^{-1}$, as well as by the change of the strong signal of the $-\mathrm{COOH}$ groups at $1720-1680 \mathrm{~cm}^{-1}$ (see Figure 5). This is a result of the acidification to $\mathrm{pH} 2$ in the precipitation step, where a residue of carboxylates is left. This is found for both azo dyes [31-33].
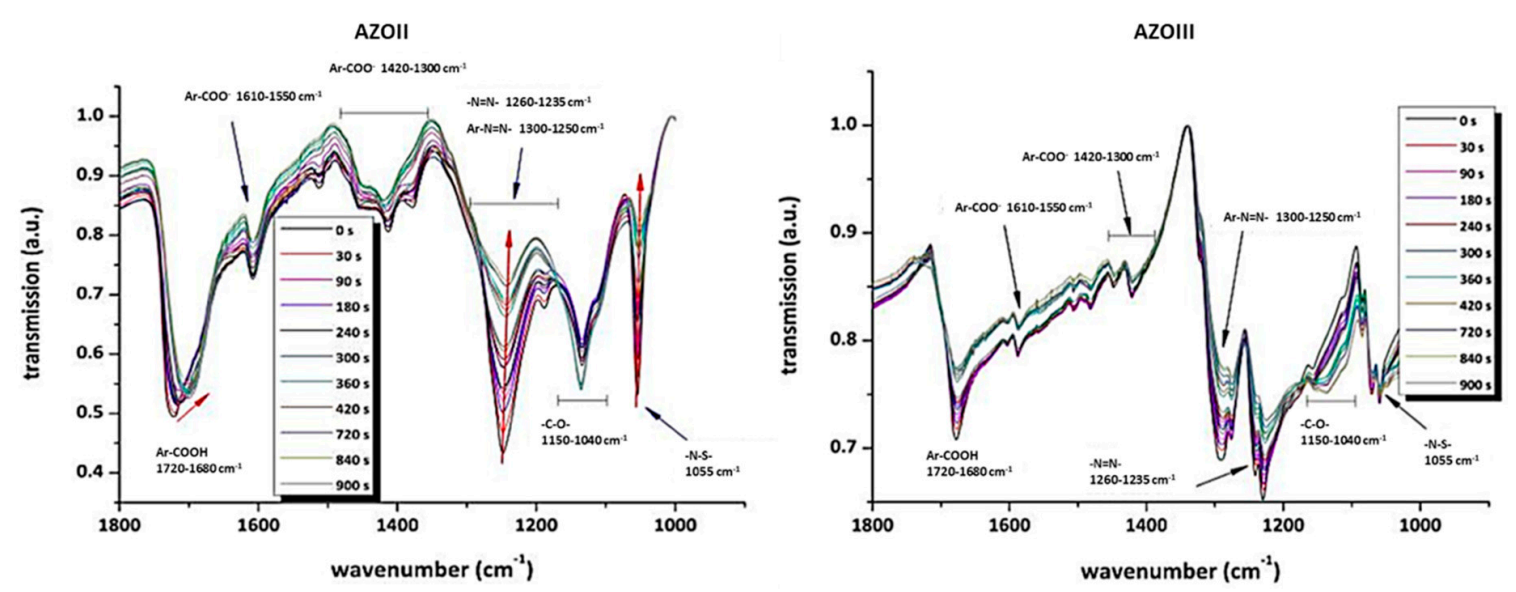

Figure 5. FTIR analysis of the AZOII (a) and AZOIII (b) dye on $\mathrm{CaF}_{2}$ platelets at different illumination times.

Irradiation leads to a decrease of the $\mathrm{Ar}-\mathrm{N}=\mathrm{N}-$ and $-\mathrm{N}=\mathrm{N}-$ stretching vibrations from 1300 to $1235 \mathrm{~cm}^{-1}$, as well as the $-\mathrm{N}-\mathrm{S}-$ stretching vibration at $1055 \mathrm{~cm}^{-1}$. As the para substituent of the aromatic systems is decomposed, the dipole moment of the whole molecule is changed, which also explains the shift of the Ar-COOH vibration for AZOII from $1720 \mathrm{~cm}^{-1}$ to lower wavenumbers. Additionally, a slight increase of the -C-O- valence vibration at 1150 to $1040 \mathrm{~cm}^{-1}$ is observed, which may be a result of hydroxyphenyl formation, according to Nuyken and Voit (compare Figure 1) [23]. As a result of UV irradiation, the azo groups of both azo dyes are decomposed, which leads to a nitrogen gas release and splitting off the sulphonic acid moiety.

This proposed decomposition mechanism is confirmed by the obtained FTIR kinetics and can also be followed by UV-Vis measurements, as the electron density of the aromatic system is altered due to UV-induced decomposition of the chromophore.

The change in the UV-Vis absorption spectra at wavelengths of 224 and $227 \mathrm{~nm}$ of both azo dyes can be assigned to changes in the electron density of the aromatic system as a result of UV-induced decomposition (see Figure $6 \mathrm{a}, \mathrm{b}$ ). As photoinduced decomposition takes place, a depletion of the absorption at $285 \mathrm{~nm}$ is observed (Figure $6 \mathrm{a}, \mathrm{b}$ ). This peak is attributed to the $\pi-\pi^{*}$ transition. The $\mathrm{n}-\pi^{*}$ transition of the chromophore azosulphonate group should occur around a wavelength of $400 \mathrm{~nm}$; however, due to the small absorption coefficient, it is not discernible [23,25,29].

As the 3,5-dicarboxyphenyl azosulphonate sodium salt exhibits high hygroscopy, it takes up aerial water which can be observed as a mass loss of $2.5 \mathrm{wt} \%$ up to $150{ }^{\circ} \mathrm{C}$ in the thermogravimetric curve, as well as an endothermic heat flow (see Figure 7a). The monoacid AZOIII, on the other hand, does not exhibit such behaviour, but it displays a higher thermal stability, with the decomposition starting at $240{ }^{\circ} \mathrm{C}$, while AZOII shows an onset of decomposition at $170{ }^{\circ} \mathrm{C}$ (Figure $7 \mathrm{a}, \mathrm{b}$ ).

This first decomposition temperature can be related to fragmentation of the azo groups, which leads to nitrogen gas emission [34]. The cleavage is very rapid for AZOIII, with a first sample weight loss of about $37 \mathrm{wt} \%$, while AZOII shows a weight loss of $25 \mathrm{wt} \%$ (compare Figure $7 \mathrm{a}, \mathrm{b}$ ). The first decomposition step is followed by decarboxylation and the decomposition of the aromatic ring, which leads to a further mass loss of $15 \mathrm{wt} \%$ for AZOII and of $10 \mathrm{wt} \%$ for AZOIII26. Finally, thermal decomposition of the residual sulphonic acid groups takes place at temperatures ranging up to $800{ }^{\circ} \mathrm{C}$ for AZOII and $750{ }^{\circ} \mathrm{C}$ for AZOIII [35]. In general, AZOII is thermally more stable, with an ash content 
of around $60 \mathrm{wt} \%$, whereas the overall weight loss for AZOIII (>80 wt \%) leads to the conclusion that the decomposition products of this substance are more volatile.

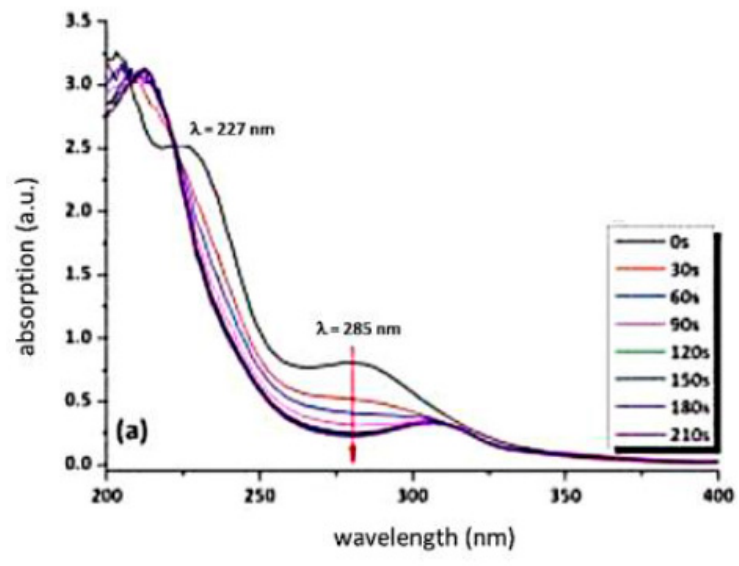

(a)

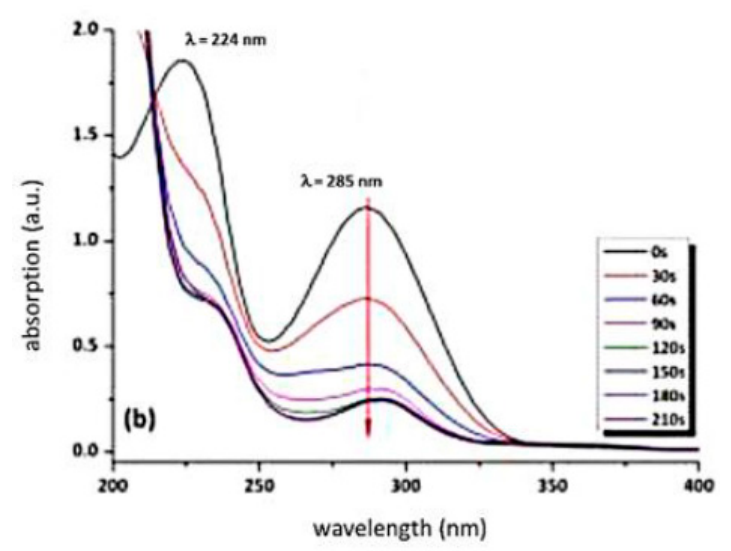

(b)

Figure 6. UV-Vis absorption spectra of aqueous solutions of (a) AZOII and (b) AZOIII upon exposure to UV light.
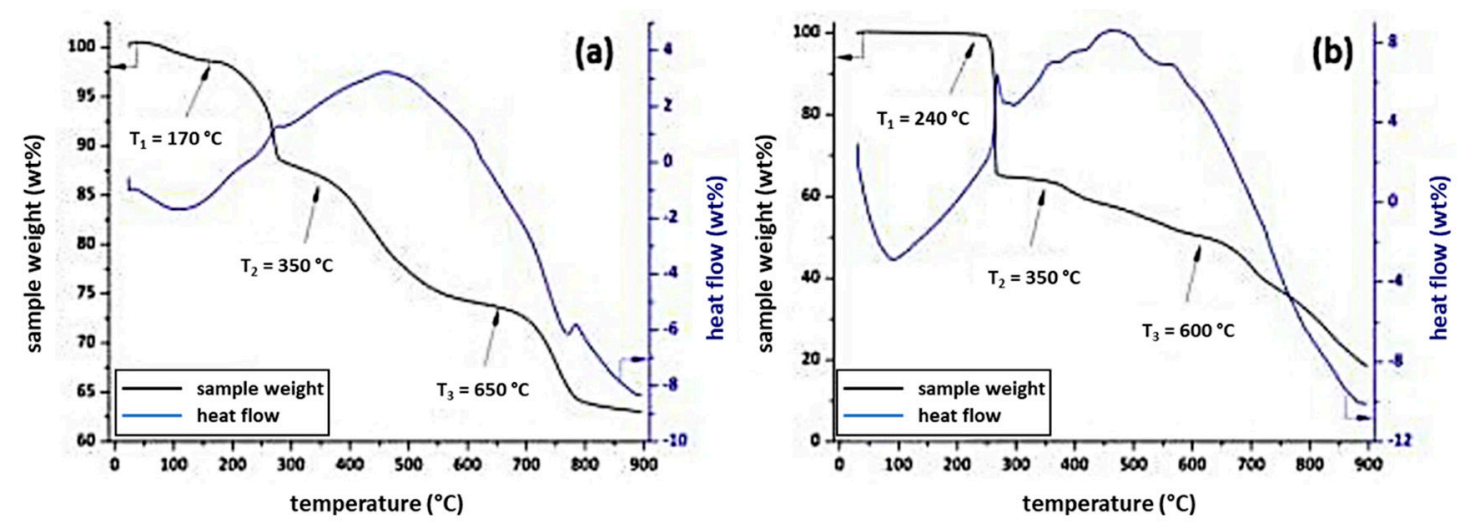

Figure 7. TGA curves (weight loss in relation to the initial sample weight) and the corresponding heat flow of (a) AZOII and (b) AZOIII.

\subsection{Characterisation of Azosulphonate-Doped PVA}

Condensation reactions and radical polymerisation enhance the crosslink density in azosulphonate-doped PVA, which could reduce the hydrophilicity and solubility of neat PVA [36]. The resulting AZO-doped PVA can be used as photoresist, where the illuminated regions are more water resistant than the non-illuminated parts, which are partly dissolved after development in water. Therefore the azosulphonates AZOII and AZOIII were used to dope poly(vinyl alcohol) to achieve a coupling between the polymeric chains (with AZOIII) or an increase in crosslinking density (with AZOII) by radical crosslinking during UV illumination. In Figure 8, the reaction to covalently link the azo dyes to PVA is shown.

The amount of the two azosulphonates in PVA was varied, and for these formulations, thin films were produced, which were subjected to further treatment (UV, heat).

Sample PAII.5 without heat treatment gives a superposition of the ${ }^{13} \mathrm{C}$ NMR spectra of the source materials (see Figure 9a). It is evident that the detection of specific $C$ atoms reaches the detection limit of the measurement system; however, it is possible to determine the structural elements, which are colour coded in Figure 9. Upon heat treatment, the formation of aromatic ester linkages can be evidenced by the splitting of the carbonyl shift at $168 \mathrm{ppm}$ into two different signals (see detail in Figure 9b) [31]. One signal is attributed to carboxylic acid, the other to ester units. 
(a)<smiles>CCCC(C)CC(C)C</smiles>

$\mathrm{m}$<smiles>O=C(O)c1cc(N=N[S-](=O)([O-])[O-])cc(C(=O)O)c1</smiles>

(b)<smiles>CCC(C)CC(C)O</smiles>

$\mathrm{m}$<smiles>[NH3+]OS(=O)(=O)N=Nc1cccc(C(=O)O)c1</smiles>

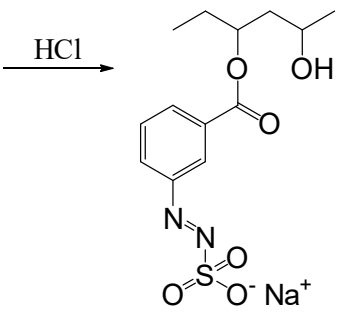

Figure 8. Mechanism of coupling reaction of aryl azosulphonates to PVA via polymer analogous esterification reaction: (a) crosslinking of PVA by coupling of AZOII; (b) coupling of monovalent AZOIII to PVA.
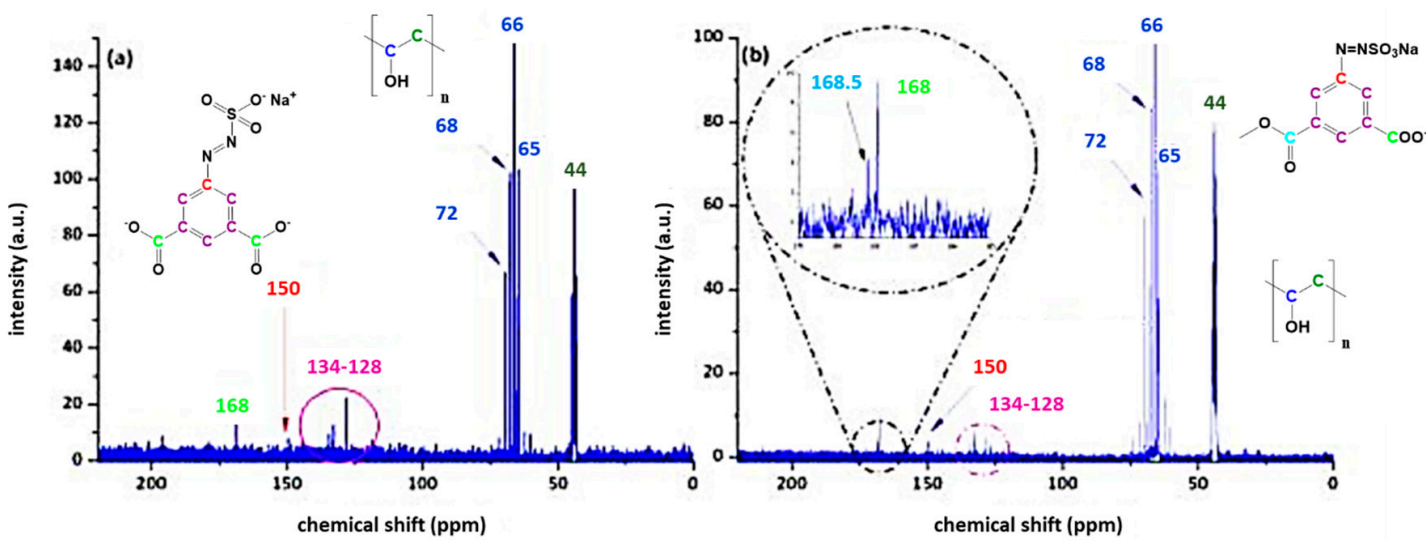

Figure 9. ${ }^{13} \mathrm{C}$ NMR of PAII.5 (comprising $20 \mathrm{wt} \%$ of AZOII) before (a) and after (b) annealing at $100{ }^{\circ} \mathrm{C}$ for $60 \mathrm{~min}$.

The coupling reaction of the monovalent acid AZOIII can also be followed by ${ }^{13} \mathrm{C}$ NMR spectroscopy and is similar to the NMR results of AZOII doped PVA (Figure 9). The evolution of a second carbonyl signal at $175 \mathrm{ppm}$ (see Figure 10b) is also attributed to an aromatic ester formation, while the signal at 169 ppm stems from non-converted carboxylic groups [37]. As these signals are in general very faint, additional FTIR measurements were conducted on thin films to ascertain these findings.
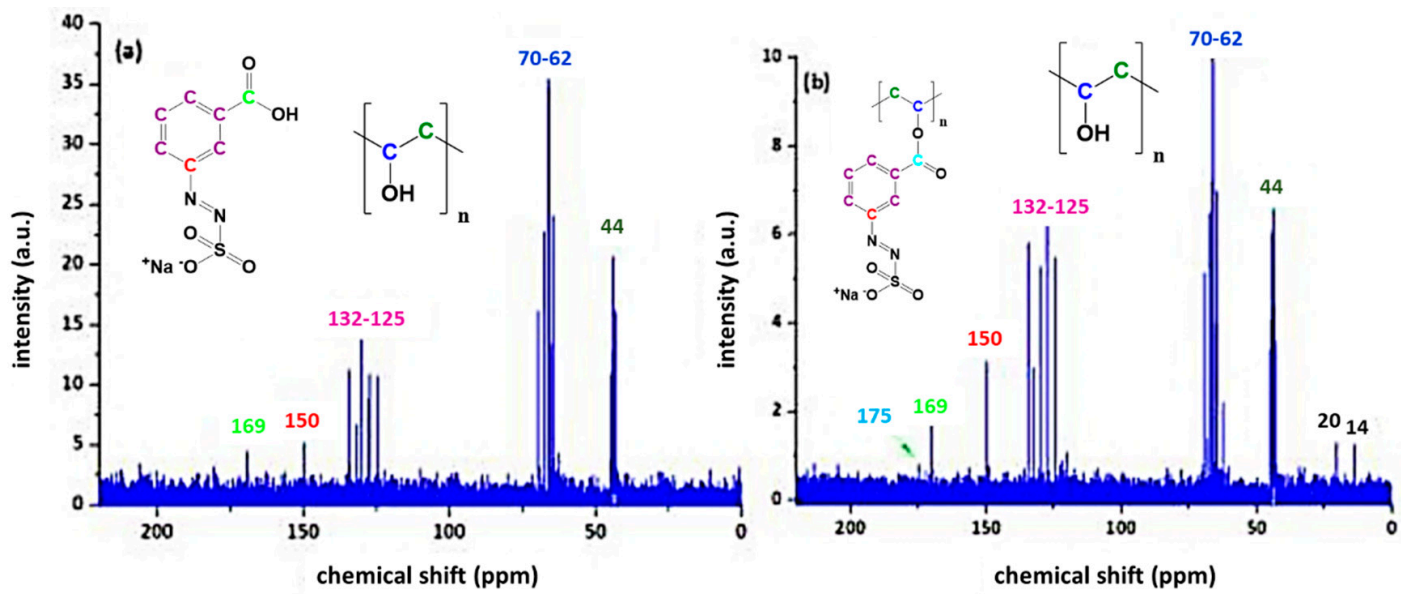

Figure 10. ${ }^{13} \mathrm{C}$ NMR of PAIII.5 (comprising $20 \mathrm{wt} \%$ of AZOII) before (a) and after (b) annealing at $100^{\circ} \mathrm{C}$ for $60 \mathrm{~min}$ 
The carboxylic groups of the AZO dyes are partially deprotonated for the pristine azosulphonates, as well as for the doped PVA films and the heat-treated samples. The formation of aromatic ester groups by condensation reaction of PVA and the azo dye is indicated by the shift of $\mathrm{C}=\mathrm{O}$ vibrations at around $1700 \mathrm{~cm}^{-1}$ to lower (AZOII) and higher wavenumbers (AZOIII) (Figure 11a-d) [31,32]. In addition, the appearance of a band prior to and after annealing at $1150 \mathrm{~cm}^{-1}$ is assigned to $\mathrm{C}-\mathrm{O}-\mathrm{C}$ bonds supporting ester formation. Despite these findings, the occurrence of the condensation reaction is uncertain. The assigned ester and carboxylic bands overlap, and the $\mathrm{C}-\mathrm{O}-\mathrm{C}$ vibration is in the same wavenumber region as the $\mathrm{C}-\mathrm{O}$ vibrations of carboxylic acid dimers. As a result, the reaction is not clearly evidenced.
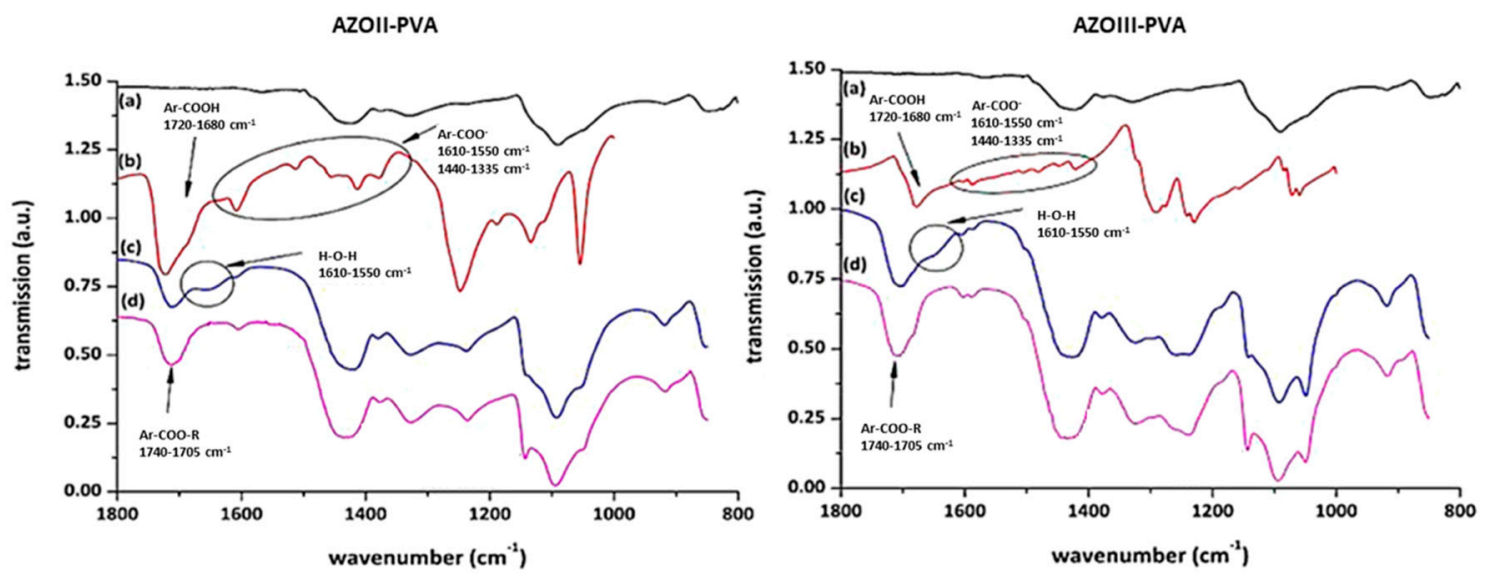

Figure 11. FTIR spectra of AZOII-PVA (left) and AZOIII-PVA (right) polymers; (a) neat PVA; (b) the respective AZO dye; (c) PAII.5/PAIII.5 containing $20 \mathrm{wt} \%$ of AZO dye; (d) PVA-AZO after 60 min of annealing at $100^{\circ} \mathrm{C}$.

After the annealing step, investigations of the photolysis kinetics were performed by UV-Vis spectroscopy. In the following section, the photolysis behaviour of PAII.5 and PAIII.5 is illustrated and discussed (Figure 12).
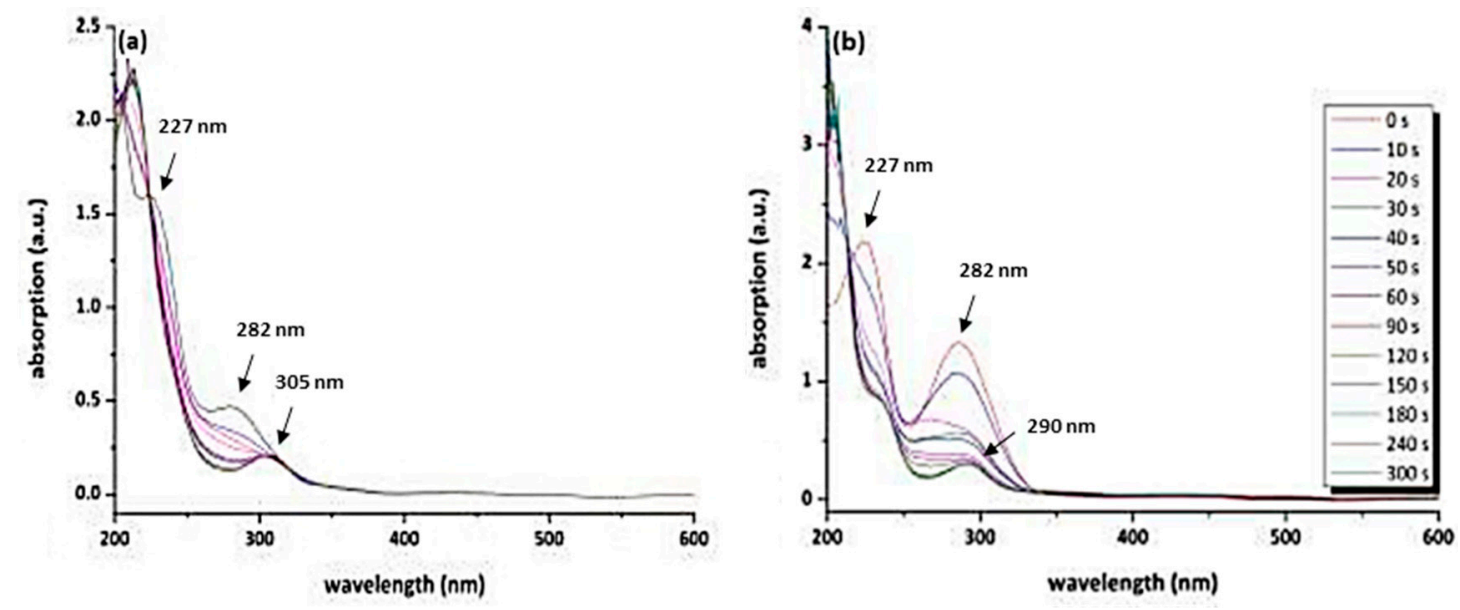

Figure 12. UV-Vis absorption spectra (a) of annealed PAII.5 and (b) of annealed thin PAIII.5 films coated onto a $\mathrm{CaF}_{2}$ substrate.

UV-Vis spectroscopy is appropriate to investigate UV-induced decomposition of the azo dye in the doped PVA films. As the electron density of the aromatic ring is altered by the cleavage of the azo group, the absorption at $227 \mathrm{~nm}$ is diminished and shifted towards lower wavelengths for both azo dyes $[26,30,38]$. The second absorption maximum at $282 \mathrm{~nm}$ (attributed to the $\pi-\pi^{*}$ transition) 
decreases as well. This leads to a bathochromic shift of the absorption to $305 \mathrm{~nm}$ for PAII.5 and to $290 \mathrm{~nm}$ for PAIII.5.

\subsection{Photolithographic Patterning}

The addition of comparatively small amounts of AZO dyes ( $2.5 \mathrm{wt} \%)$ leads to well-resolved linear patterns with sharp boundaries, which give topographical features after development. In general, the photoactivity for PVA films containing the carboxylic acid AZOIII is way better compared to AZOII-doped PVA films and leads to a good contrast behaviour of the patterned samples (see Figures 13 and 14). The crosslinking of PVA chains by radical decomposition of the covalently bound AZO dye plays a more important role in PVA-AZOIII thin films than in AZOII-doped PVA, where crosslinking had already occurred during annealing by condensation reactions. It is also observed that with increasing dye content, the number of surface defects increases after development, which is caused by outgassing of cleavage products (nitrogen gas).
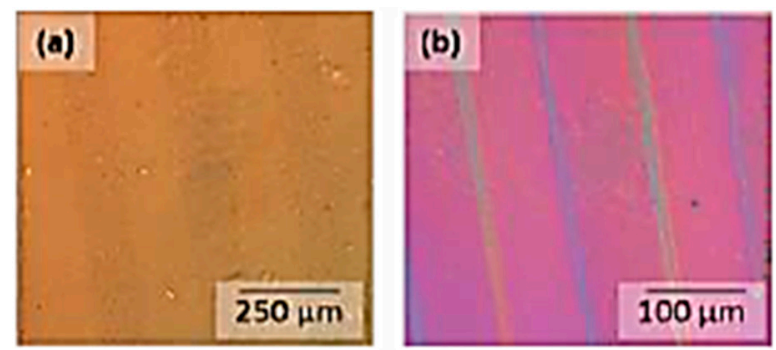

Figure 13. Phase contrast image of thin patterned PAII.1 films (a) and after development in deionised water $(\mathbf{b})$.
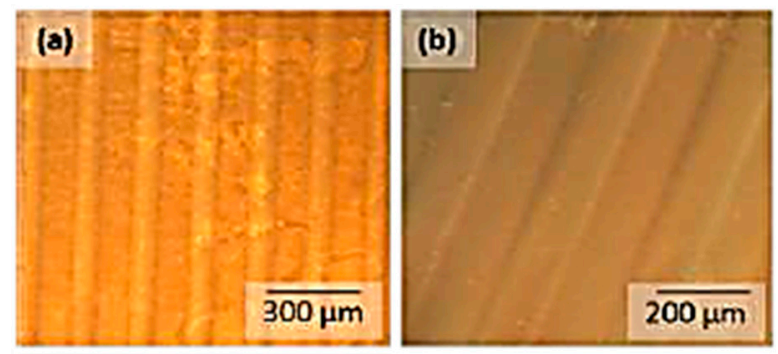

Figure 14. Phase contrast image of thin patterned PAIII.1 films (a) and after development in deionised water (b).

Samples containing $20 \mathrm{wt} \%$ of photoactive species appear grainy, which may be caused by phase separation during the drying step. During development of such samples (PAIII.5), extensive gas bubble formation occurs after a short time in deionised water (see Figure 15b).
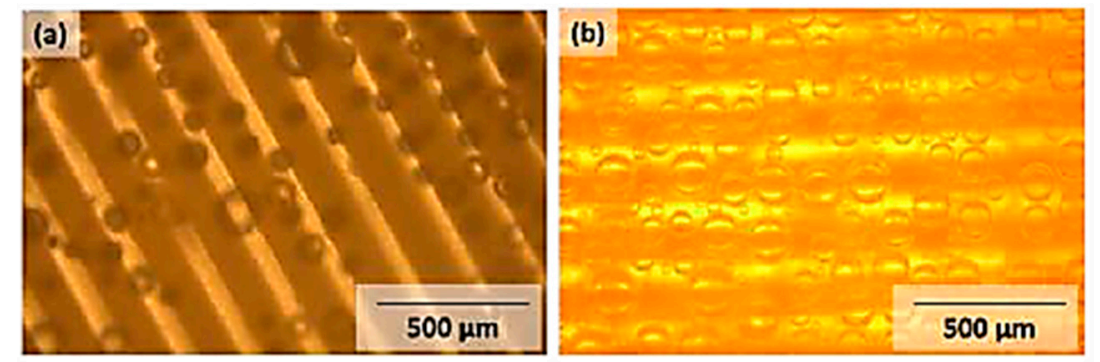

Figure 15. Gas bubble formation upon the development of patterned samples (100 $\mu \mathrm{m}$ features; dose: $45 \mathrm{Jcm}^{-2}$ ) in deionised water using phase contrast imaging mode. (a) PAII.5; (b) PAIII.5. 
The obtained structures are a result of decomposition of the chromophore azo groups and the release of nitrogen gas. During the development step, gas bubble formation, most likely nitrogen gas resulting from UV-induced cleavage of the azosulphonate dyes, takes place. The bubbles are formed in the illuminated areas (bright lines, see Figure 15), thus giving further evidence that the patterning step is the origin of this effect.

\section{Conclusions}

Water-soluble aryl azosulphonate dyes with carboxylic moieties attached to the aromatic ring (AZOII/ZOIII) were prepared in accordance to published work $[23,26]$. The photolytic behaviours of AZOII and AZOIII were investigated by decomposition in aqueous solution, providing information that the electron density of the aromatic ring is changed by UV-induced cleavage of the $-\mathrm{N}=\mathrm{N}-\mathrm{SO}_{3}{ }^{-}$ group. These results are confirmed by FTIR spectroscopy of thin films on $\mathrm{CaF}_{2}$ platelets, by the depletion of the $-\mathrm{C}-\mathrm{N}=\mathrm{N}-$ and $-\mathrm{N}=\mathrm{N}-$ absorption bands, as well as by the $-\mathrm{N}-\mathrm{S}-$ absorption. Thermolysis experiments demonstrate the high-temperature stability of the prepared photoactive dyes, with decomposition temperatures higher than $170{ }^{\circ} \mathrm{C}$ for the dicarboxylic acid AZOII, and $240{ }^{\circ} \mathrm{C}$ for AZOIII.

In a novel approach, the prepared aryl azosulphonate compounds were covalently attached to poly(vinyl alcohol). At first, the coupling between the photoactive carboxylic acids and the polymer by heat-induced esterification was studied. Due to detection limit issues, it is difficult to prove the coupling reaction of the carboxylic moieties and the hydroxyl groups of the polymer by means of FTIR and ${ }^{13} \mathrm{C}$ NMR spectroscopy. UV-Vis spectroscopy was employed due to its enhanced sensitivity to visualise UV-induced changes in the prepared materials. As neat PVA exhibits no UV absorption, changes in the absorption spectra result from photolytic cleavage of the azosulphonate units, which can be attributed to the $\pi-\pi^{*}$ transition, whereas the $n-\pi^{*}$ transition is not discernible due to the low absorption coefficient.

These novel UV-reactive materials exhibit good contrast behaviour after photolithographic patterning, which can be visualised by polarised light and phase contrast imaging. This leads to the conclusion that changes of the optical contrast of the thin films are a result of the cleavage of the azosulphonate groups. For samples containing a high content (20 wt \%) of azo sulphonate, strong gas bubble formation is observed during the development of the illuminated samples.

Due to the thermal stability of both the azosulphonate compounds and PVA, applications for high-temperature coatings with tuneable polarity depending on the chemical environment would be possible, e.g., waveguides, optical components. Further adaptions concerning the coupling process of the azosulphonates onto the polymer backbone could lead to full conversion of the carboxylic moieties.

Author Contributions: Conceptualisation, P.N. and G.R.; methodology, J.G.S.; validation, P.N. and G.R. investigation, J.G.S.; writing-original draft preparation, P.N. and G.R.; writing-review and editing, G.R. and W.K; supervision, W.K.; project administration, G.R.

Funding: The research was not funded.

Acknowledgments: The authors want to thank Anton Huber of the Institute of Chemistry (University of Graz, Austria) for the GPC measurements of the polymer sample.

Conflicts of Interest: The authors declare no conflict of interest.

\section{References}

1. Yamadaa, S.; Medeiros, D.R.; Patterson, K.; Jen, W.L.K.; Rager, T.; Lin, Q.; Lenci, C.; Byers, J.D.; Havard, J.M.; Pasini, D.; et al. Positive and Negative Tone Water Processable Photoresists: A Progress Report. Proc. SPIE Int. Soc. Opt. Eng. 1998, 3333, 245-253.

2. Lin, Q.; Steinhäusler, T.; Simpson, L.; Wilder, M.; Medeiros, D.R.; Willson, C.G. A Water-Castable, Water-Developable Chemically Amplified Negative-Tone Resist. Chem. Mater. 1997, 9, 1725-1730. [CrossRef]

3. Aoki, H.; Tokuda, T.; Nagasaki, Y.; Kato, M. Water-soluble silicon containing polymer resist. J. Polym. Sci. Part A Polym. Chem. 2000, 35, 2827-2833. [CrossRef] 
4. Shirai, M.; Katsuta, N.; Tsunooka, M.; Tanaka, M.; Nishijima, K. Photosensitive polymers bearing iminooxysulfonyl groups. A water soluble positive-type photoresist. Die Makromol. Chem. 1989, 190, 2099-2107. [CrossRef]

5. Barker, I.C.; Allen, N.S.; Edge, M.; Sperry, J.A.; Batten, R.J. Synthesis, photochemistry and cross-linking of visibly sensitised photopolymers of PVA based on (E)-2-(4-Formylstyryl)-3,4-dimethylthiazolium Methylsulfate. J. Chem. Soc. Faraday Trans. 1994, 90, 3677-3683. [CrossRef]

6. Dauth, J.; Nuyken, O.; Strohriegl, P.; Voit, B. Water-soluble photoresins based on azosulfonates. Die Makromol. Chem. 1992, 193, 723-734. [CrossRef]

7. Aslam, M.; Kalyar, M.A.; Zulfiqar Ali Raza, Z.A. Polyvinyl alcohol: A review of research status and use of polyvinyl alcohol based nanocomposites. Polym. Eng. Sci. 2018, 58, 2119-2132. [CrossRef]

8. Suganthi, S.; Mohanapriya, S.; Raj, V.; Kanaga, S.; Dhandapani, R.; Vignesh, S.; Sundar, K.J. Tunable Physicochemical and Bactericidal Activity of Multicarboxylic-Acids-Crosslinked Polyvinyl Alcohol Membrane for Food Packaging Applications. Chem. Sel. 2018, 3, 11167-11176. [CrossRef]

9. Desmaisons, J.; Rueff, M.; Brasa, J.; Dufresne, A. Impregnation of paper with cellulose nanocrystal reinforced polyvinyl alcohol: Synergistic effect of infrared drying and CNC content on crystallinity. Soft Matter 2018, 14, 9425-9435. [CrossRef]

10. Finch, C.A. Polyvinyl Alcohol: Properties and Applications; Finch, C.A., Ed.; Wiley: New York, NY, USA, 1973.

11. So, J.-H.; Oh, M.-H.; Lee, J.-D.; Yang, S.-M. Effects of Polyvinyl Alcohol on the Rheological Behavior and Phase Stability of Aqueous Silica Suspensions. J. Chem. Eng. 2001, 34, 262-268. [CrossRef]

12. Mawad, D.; Martens, P.J.; Odell, R.A.; Poole-Warren, L.A. The effect of redox polymerisation on degradation and cell responses to poly (vinyl alcohol) hydrogels. Biomaterials 2007, 28, 947-955. [CrossRef] [PubMed]

13. Pal, K.; Banthia, A.K.; Majumdar, D.K. Biomedical evaluation of polyvinyl alcohol-gelatin esterified hydrogel for wound dressing. J. Mater. Sci. Mater. Med. 2007, 18, 1889-1894. [CrossRef]

14. Braun, D.; Walter, E. Intra- und intermolekulare Vernetzung von Polyvinylalkohol mit Dialdehyden. Colloid Polym. Sci. 1980, 258, 795-801. [CrossRef]

15. Pal, K.; Banthia, A.K.; Majumdar, D.K. Preparation and characterization of polyvinyl alcohol-gelatin hydrogel membranes for biomedical applications. AAPS PharmSciTech 2007, 8, E142-E146. [CrossRef] [PubMed]

16. Schauberger, J.G.; Riess, G.; Kern, W. UV crosslinking of Fe3+-doped poly(vinyl alcohol)—Characterization of optical properties and swelling behavior. J. Appl. Polym. Sci. 2013, 129, 3623-3628. [CrossRef]

17. Filoti, G.; Kuncser, V.; Franke, H.; Kardinahl, T.; Manivannan, G. Optical induced modifications in thin films of Fe:PVA. J. Radioanal. Nucl. Chem. 1995, 190, 315-320. [CrossRef]

18. Guiot, O.; Tighzert, L.; Coqueret, X. Electron beam crosslinking of extrusion-blown LDPE films: 1. Mechanical properties. Eur. Polym. J. 1999, 35, 565-570. [CrossRef]

19. Barichard, A.; Israëli, Y.; Rivaton, A. Photocrosslinking in dichromated poly(acrylic acid) during hologram recording and comparison with dichromated poly(vinyl alcohol). J. Polym. Sci. Part A Polym. Chem. 2007, 46, 636-642. [CrossRef]

20. Bulinski, M.; Iova, I.; Belea, A.; Kuncser, V.; Filoti, G. Experimental investigation of the nonlinear optical response in Fe:PVA. J. Mater. Sci. Lett. 2000, 19, 27-28. [CrossRef]

21. Schauberger, J.G.; Riess, G.; Kern, W. Preparation of UV reactive montmorillonite and characterization of its nanocomposites with poly(vinyl alcohol). J. Appl. Polym. Sci. 2013, 130, 665-672. [CrossRef]

22. Tang, Z.; Wie, J.; Yung, L.; Ji, B.; Ma, H.; Qiu, C.; Yoon, K.; Wan, F.; Fang, D.; Hsiao, B.S.; et al. UV-cured poly(vinyl alcohol) ultrafiltration nanofibrous membrane based on electrospun nanofiber scaffolds. J. Memb. Sci. 2009, 328, 1-5. [CrossRef]

23. Nuyken, O.; Voit, B. The photoactive diazosulfonate group and its role in polymer chemistry. Macromol. Chem. Phys. 2003, 198, 2337-2372. [CrossRef]

24. Overberger, C.G.; O'Shaughnessy, M.T.; Shalit, H. The Preparation of Some Aliphatic Azo Nitriles and their Decomposition in Solution. J. Am. Chem. Soc. 1949, 71, 2661-2666. [CrossRef]

25. Matusche, P.; Nuyken, O.; Voit, B.; Damme, M.V. Water Soluble and Photoactive Copolymers Containing Amidic Aryldiazosulfonate Groups. J. Macromol. Sci. Part A 1997, 34, 201-209. [CrossRef]

26. Riess, G. Neue Arylazosulfonate und ihre Reaktionen. Master's Thesis, University of Bayreuth, Bayreuth, Germany, 1990.

27. Nuyken, O.; Presenz, U. Azo polymers-Syntheses and reactions. Polym. Bull. 1988, 20, 335-341. [CrossRef] 
28. Staško, A.; Szaboova, K.; Cholvad, V.; Nuyken, O.; Dauth, J. The photochemical decomposition of azo compounds (a spin trap study). J. Photochem. Photobiol. A Chem. 1993, 69, 295-304. [CrossRef]

29. Franzke, D.; Scherer, C.; Nuyken, O.; Wokaun, A. Synthesis and photochemical properties of aromatic diazo-phosphonium salts. J. Photochcem. Photobiol. A Chem. 1997, 111, 47-50. [CrossRef]

30. Voit, B.; Braun, F.; Gernert, M.; Sieczkowska, B.; Millaruelo, M.; Messerschmidt, M.; Mertig, M.; Opitz, J. Photolabile and thermally labile polymers as templates and for surface patterning. Polym. Adv. Technol. 2006, 17, 691-693. [CrossRef]

31. Hesse, M.; Meier, H.; Zeeh, B. Spektroskopische Methoden in der Organischen Chemie; Thieme Verlag: Stuttgart, Germany, 2005.

32. Socrates, G. Infrared Characteristic Group Frequencies, 2nd ed.; John Wiley \& Sons: New York, NY, USA, 1994.

33. McKnight, D.M.; Kimball, B.A.; Runkel, R.L. pH dependence of iron photoreduction in a rocky mountain stream affected by acid mine drainage. Hydrol. Process. 2001, 15, 1979-1992. [CrossRef]

34. Kocaokutgen, H.; Gümrükçüoèlu, I.E. Thermal Characterization of Some Azo Dyes Containing Intramolecular Hydrogen Bonds and Non-Bonds. J. Therm. Anal. Calorim. 2003, 71, 675-679. [CrossRef]

35. Holt, B.D.; Engelkemeir, A.G. Thermal decomposition of barium sulfate to sulfur dioxide for mass spectrometric analysis. Anal. Chem. 1970, 42, 1451-1453. [CrossRef]

36. Schauberger, J.G. Polymere als Barrierematerialien für Kartonverpackungen. Master's Thesis, Montanuniversitaet Leoben, Leoben, Austria, 2009.

37. Knopp, D.; Tang, D.; Niessner, R. Review: Bioanalytical applications of biomolecule-functionalized nanometer-sized doped silica particles. Anal. Chim. Acta 2009, 647, 14-30. [CrossRef] [PubMed]

38. Mustroph, H.; Epperlein, J. Untersuchungen zum UV/Vis-Spektralverhalten von Azofarbstoffen. V Quantitative Beschreibung der Absorptionsmaxima mehrfach substituierter Azobenzene mit einem Inkrementsystem. J. Prakt. Chem. 1981, 323, 755-775. [CrossRef]

(C) 2019 by the authors. Licensee MDPI, Basel, Switzerland. This article is an open access article distributed under the terms and conditions of the Creative Commons Attribution (CC BY) license (http:/ / creativecommons.org/licenses/by/4.0/). 